\title{
ESTIMATION OF FUTURE METHANE PRODUCTION FROM HELLENIC LANDFILLS
}

\section{T. TSATSARELIS* \\ A. KARAGIANNIDIS}

Received: $14 / 09 / 08$

Accepted: 01/12/08

\author{
Laboratory of Heat Transfer and Environmental Engineering \\ Department of Mechanical Engineering \\ Box 483, Aristotle University, 54124 Thessaloniki, Hellas
}

*to whom all correspondence should be addressed: e-mail: ttsatsar@aix.meng.auth.gr

\begin{abstract}
The main objective of this research was to predict expected methane generation in Hellenic sanitary landfills, in order to evaluate its potential for energy production and to ensure health and safety in and around these sites on the long term. The study was performed for the period 2008 - 2028 with the use of a multi-phase model and included also a sensitivity analysis in order to determine the impact of certain waste parameters. In this context, two 'extreme' reference scenarios were formulated and assessed, one anticipating fulfilment of the EU landfill directive (which sets limits to the amount of biodegradable and packaging materials to be deposited in sanitary landfills) whereas a second (do-nothing scenario) assuming no such timely compliance.
\end{abstract}

KEYWORDS: Landfill gas, Sanitary landfills, Energy recovery, waste composition, waste disposal.

\section{INTRODUCTION}

Organic waste decomposition leads to the production of Landfill Gas (LFG), which can cause explosions and asphyxiation, has an unpleasant odour (caused by trace gases such as mercaptans and hydrogen sulphide) and displaces oxygen in the surrounding soils therefore inhibiting the natural growth of local vegetation. According to (Falzon, 1997), methane production in landfills typically begins 6 to 12 months after waste placement, then rises to a maximum shortly after landfill closure and, finally, gradually declines over a period of 30-50 years. According to Tchobanoglous et al. (1993), 5\% of the total methane production is produced immediately after the closure of a landfill cell and according to Qin et al. (2001), gas production starts immediately after the Municipal Solid Waste (MSW) deposition and attains its peak production rate in about 10 years, whereas one ton of MSW can produce up to 300 $\mathrm{m}^{3}$ of LFG. On the other hand USEPA, on the basis of experimental work has estimated the total methane generation in landfills to be $92 \mathrm{~N} \mathrm{~m}^{3}$ tonne ${ }^{-1}$ of dry MSW (Themelis and Karagiannidis, 2008).

LFG mainly consists of methane $\left(\mathrm{CH}_{4}\right)$ and carbon dioxide $\left(\mathrm{CO}_{2}\right)$ and according to Parker et al. (2002) it also includes 140 trace components, 90 of which were common to all studied landfill sites. According to another study (Deed et al., 2004) though, there are more than 500 trace compounds in landfill gas. The typical concentration of methane in LFG is between 35 60\% (Falzon, 1997; Tchobanoglous et al., 1993; Deed et al., 2004; Nikiema et al., 2005).

It is common understanding now that LFG should be considered either as a significant source of pollution and risk (if migrating uncontrollably to the air and ground), or as a significant source of renewable energy (if extracted and processed accordingly). There are two possible solutions for dealing with LFG emissions. In case of low methane ratios, LFG should be extracted and flared or oxidized in biofilters. On the other hand, in case of high methane content, LFG becomes an evidently valuable energy resource, as it is then able to sustain the fuelling of engines producing electricity and thermal energy. More specifically, it can be used 
as a supplementary or primary fuel to increase the production of electric power, as a pipeline quality gas and vehicle fuel, or even as a supply of heat and carbon dioxide for greenhouses and various industrial processes. Reported technologies that utilize LFG include i.a. internal combustion engines, gas turbines, fuel cells and boiler systems (Tsatsarelis et al., 2006a). Methods and models for predicting LFG generation first appeared in the early 1970's. Cossu et al (1996) stated the following definition of model types: "The greatest absolute exponent $n$ of the dependent variable $\left(\frac{d C}{d t}=f(t, C n)\right.$, where t: time, $C$ : the amount of methane generated or degradable substrate) is called the order of the model (Lamborn, 1999). The first types of models tried to use limited data in order to develop a rational basis for the predictions. Some of this work was carried out by Ham (1979), Farquhar and Rovers (1973) and Rees (1980) and more zero- and first-order kinetic models then appeared (Pacey and Augenstein, 1990; Richards et al., 1992; Coops et al., 1995), while models using fractal-like kinetics have also been recently introduced (Meraz et al., 2004). There have been a number of comparisons between different types of models (Lamborn, 1999; Scharff and Jacobs, 2006) which concluded that multi-phase models are the most accurate ones; therefore, a multi-phase model was chosen to be used in the current study.

Purpose of this study is the estimation of methane which is and will be produced in new Hellenic sanitary landfills. Up to now, LFG emissions have been estimated by Greece in order to comply with the United Nations Framework Convention on Climate Change (UNFCCC). The present study goes beyond this past work in (a) predicting future methane emissions, (b) using actual (also partially self-collected) data for a number of sanitary landfills and, in the cases where no such data were available, (c) laying out more reliable, pragmatic and updated working assumptions.

\section{METHODOLOGY}

\subsection{Estimation model}

The model used here for methane estimation is a multi-phase model developed by the Norwegian Pollution Control Authority (Statens forurensningstilsyn, SFT) for the calculation of methane emissions from MSW disposal sites. This model is in full compliance both with the Revised Intergovernmental Panel on Climate Change (IPCC) Guidelines for National Greenhouse Gas inventories, as well as the IPCC Good Practice Guidance and Uncertainty Management in National Greenhouse Gas Inventories as approved by the UNFCCC (Tsatsarelis et al., 2006b).

\subsection{Selected coefficients}

In non-engineered (mostly shallow) old landfills, a large part of the deposited waste degrades under aerobic conditions. Methane Correction Factor (MCF) is defined as the part left to degrade under anaerobic conditions. For engineered sites (sanitary landfills), MCF was set to 1 for all materials. The Degradable Organic Carbon (DOC) is the organic carbon that is accessible to biochemical decomposition; default model settings were used: for food waste, the DOC factor was set at 0.17 , for paper at 0.385 and for wood and textiles at $0.4 . D D_{f}$ is the part of DOC which dissimilates under anaerobic conditions; default settings were also used for $\mathrm{DOC}_{\mathrm{f}}$, which was thus set at 0.5 for all types of waste. Furthermore due to lack of more detailed data for the sites in question, LFG was considered to be composed of $50 \%$ $\mathrm{CH}_{4}$. The basis for a first-order kinetics reaction is a reaction starting with the full amount of reactant, going with a constant reaction rate $(\mathrm{k})$, which depends on parameters such as moisture, temperature, $\mathrm{pH}$, biochemical feedback, density of waste, etc (Falzon, 1997; Munoz et al., 2003). The estimation of $\mathrm{k}$ is empirical and is based on experimental data. For the current study, the values proposed by Scharff and Jacobs (2006) were used as shown in table 1 . Food waste is considered as rapidly degradable waste, paper as moderately degradable, whereas wood and textiles as slowly degradable.

Table 1. Reaction rate for rapidly, moderately and slowly degradable materials

\begin{tabular}{ccc}
\hline Rapidly degradable $\left(\mathrm{k}_{1}\right)$ & Moderately degradable $\left(\mathrm{k}_{2}\right)$ & Slowly degradable $\left(\mathrm{k}_{3}\right)$ \\
0.187 & 0.099 & 0.030 \\
\hline
\end{tabular}




\subsection{Selected data}

For the implementation of the model, 2008 was chosen as the starting year for waste deposition in new sanitary landfills, due to the fact that, by the end of this year (following also a series of postponements) all still open non-engineered disposal sites have to be closed and the generated waste should be rerouted to recycling and recovery facilities and to sanitary landfills. However, methane produced by the three biggest Hellenic semi-controlled landfills, was estimated as well: one at 'Shisto' (operated in the period 1960-1991) in Attiki, one at 'Ano Liossia' (initiated at 1973 in Attiki) and one at 'Tagarades' (initiated at 1981 in Thessaloniki and closed in mid 2008). 2028 was chosen as a working assumption for the last year of waste disposal at the considered sites, although LFG will clearly continue to be produced for a long time after then. Data about the composition of waste related to methane generation were gathered for different areas in Greece from published studies and contacts with landfill operators and municipalities. Table 2 shows composition of waste in various Hellenic areas and figure 1 shows their location.

For the 'landfill directive' scenario, biodegradable waste should be decreased by $25 \%$ by the year 2010 , by $50 \%$ by the year 2013 and by $65 \%$ by the year 2020 , having the year 1995 as reference point (EC/1999/31). Furthermore, by 31-12-2005, packaging materials should have been recycled by $25-45 \%$ (with a minimum $15 \%$ recycling goal for each material) and by $31-$ 12-2008 paper and cardboard by $60 \%$ and wood by $15 \%$. All these changes in the composition were considered to have a linear reduction over time. In case of Thessaloniki, detailed data on the amounts of deposited waste from 1981 to 2005 was available; therefore, the trend of deposited waste could be calculated more accurately. Linear regression was considered adequate as the deviation between the calculations and the actual data on the amounts of waste was between 2-6\%. For the Kozani landfill, the increase of deposited waste was also available. For all other landfills, the deposited types of waste (food waste, paper, wood, and textiles) were assumed to have a $3 \%$ increase as calculated by official data (Hellenic Official Gazette, 2003). Data were also available for the sanitary landfills of Ano Liossia, Larissa, Volos, Xanthi, Kavala, Kilkis, Zakinthos, Kefalonia, Patra, Levadeon, Domokos, Lamia, Rethimno, Sitia, Amario and Katerini (cf. also Figure 1).

In case where data about the amounts of landfilled waste were not available, these were calculated by multiplying the population of each Prefecture with its waste generation rate. The waste generation rate was divided into two categories as shown in table 3 and an increase of $3 \%$ in the deposited waste was also assumed. Figure 2 shows the quantities of MSW which were produced in Greece for the period 1960 - 2008, as calculated according to the population, waste generation rates and data gathered via literature review. It must be noted that there is a significant gap in such kind of official calculations and temporal data on waste generation at a country level in Greece and the present study aspired to also set some impulse in proceeding with more elaborated versions of such kinds of historical time-series waste generation analysis and disaggregation. Furthermore, MSW quantities landfilled at Shisto, Ano Liossia, Tagarades and other major sanitary landfills, as well as the quantities recycled or utilized in other ways (compost, RDF) were also estimated. These calculations are illustrated in Figure 3.

When information on a planned sanitary landfill was not available, it was assumed that one such site would serve each (of the 51) Hellenic Prefecture, an assumption that in general fits to the current planning of solid waste management in the country. However, it must be noted that in some Prefectures (such as Pieria, Pella, Chalkidiki, Achaia and Fthiotida) already, more than 2 sanitary landfills do (or are planned to) operate. In such cases, total methane produced in these Prefectures was calculated. 
Table 2. Reported measurements on waste composition and other properties in various Hellenic areas

\begin{tabular}{|c|c|c|c|c|c|c|c|c|c|c|c|c|c|c|c|c|c|c|c|c|c|c|}
\hline \multirow{2}{*}{\begin{tabular}{|l} 
Area \\
Time period
\end{tabular}} & \multicolumn{6}{|c|}{ 苋 } & \multicolumn{2}{|c|}{ 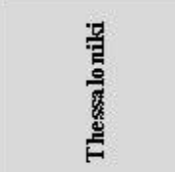 } & \multirow{2}{*}{ 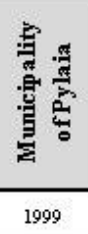 } & \multirow{2}{*}{ 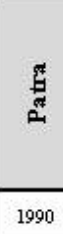 } & \multirow{2}{*}{ 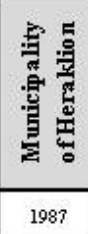 } & \multirow{2}{*}{ 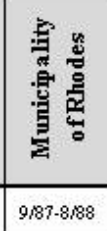 } & \multirow{2}{*}{ 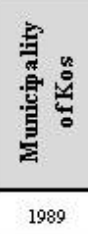 } & \multirow{2}{*}{ 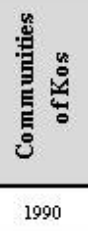 } & \multirow{2}{*}{ 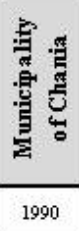 } & \multirow{2}{*}{ 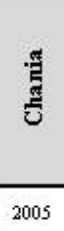 } & \multirow{2}{*}{ 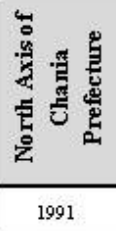 } & \multirow{2}{*}{ 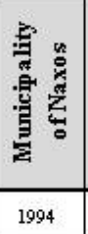 } & \multirow{2}{*}{ 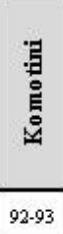 } & \multirow{2}{*}{ 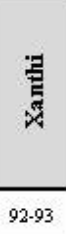 } & \multirow{2}{*}{ 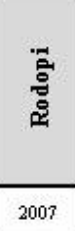 } & \multirow{2}{*}{ 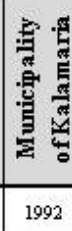 } \\
\hline & 1969 & 1970 & 1971 & 1972 & $6 / 83-6884$ & 2005 & $4 / 86-3 / 87$ & 2003 & & & & & & & & & & & & & & \\
\hline Population & & & $3.5 \mathrm{mil}$ & & & & $1 \mathrm{~m}$ & & & & 115,000 & 45,000 & 15,000 & 12,000 & & & 50,000 & & & & 100,717 & 60,000 \\
\hline Orgaric (\% w/w) & 55.3 & 57.2 & 57.5 & 60.9 & 59.8 & 25.30 & 51.7 & 26.7 & 46.7 & 41.2 & 52.5 & 41.6 & 37.3 & 39.8 & 55.2 & 30 & 54.8 & 48.3 & 67.1 & 61.2 & 43.5 & 47 \\
\hline Paper (\% w/w) & 24.4 & 23.2 & 23.3 & 22.0 & 19.5 & 40 & 17.7 & 29.2 & 21.7 & 21.9 & 17.2 & 13.6 & 25.0 & 23.5 & 19.1 & 17.7 & 18.1 & 21.6 & 9.1 & 15.1 & 18.3 & 25.0 \\
\hline \begin{tabular}{|l} 
Printing pqper \\
Paper board
\end{tabular} & & & & & & & & & & & & & $\frac{4.8}{2.9}$ & $\frac{4.9}{2.0}$ & $\begin{array}{l}5.7 \\
2.5\end{array}$ & & $\frac{5.3}{3.1}$ & $\begin{array}{l}4.5 \\
3.7\end{array}$ & & & & $\begin{array}{ll}3.1 \\
8.7\end{array}$ \\
\hline Aseptic packaging & & & & & & & & & & & & & 2.6 & 2.9 & 1.5 & & 1.9 & 2.1 & & & & 1.7 \\
\hline Other paper & & & & & & & & & & & & & 14.7 & 13.7 & 9.4 & & 7.8 & 11.3 & & & & 11.5 \\
\hline \begin{tabular}{|l} 
Metals (\% w/w) \\
\end{tabular} & 4.6 & 4.4 & 4.2 & 3.9 & 3.8 & & 5.9 & 3.4 & 3.5 & & 2.8 & 10.5 & 5.4 & 5.3 & 3.7 & 4.1 & 3.9 & 3.4 & 2.8 & 3.2 & 3.7 & 3.5 \\
\hline $\begin{array}{l}\text { Ferrous } \\
\end{array}$ & & & & & & & & & & & & & 3.2 & 3.1 & 2.8 & & 2.7 & 2.1 & & & & 2.8 \\
\hline Aluminum & & & & & & & & 1.1 & & 0.5 & & & 2 & 2 & 0.9 & & 1.1 & 1.1 & & & & 0.6 \\
\hline Batteries & & & & & & & & & & & & & 0.2 & 0.1 & & & 0.1 & 0.1 & & & & 0.1 \\
\hline Glass (\% w/w) & 3.8 & 3.8 & 2.6 & 2.2 & 2.6 & & 4.1 & 3.6 & 3.3 & 1.3 & 1.4 & 12.6 & 12.3 & 9.6 & 4 & 4 & 3.5 & 5.8 & 1.7 & 2.1 & 3.5 & 2.6 \\
\hline \begin{tabular}{|l} 
Plastic (\% w/w) \\
\end{tabular} & 7.4 & 8.0 & 10.0 & 9.3 & 7 & 17 & 7.2 & 17.9 & 12.8 & & 14.3 & 11.7 & 10.9 & 11.4 & 8.3 & 12.5 & 8.8 & 9.4 & 6.1 & 7.1 & 17.8 & 7.4 \\
\hline \begin{tabular}{|l} 
PE leaf \\
\end{tabular} & & & & & & & & & & & & & 4.8 & 4.9 & 5.6 & & 5.5 & 4.4 & & & & 5.1 \\
\hline PVC & & & & & & & & & & & & & 1.4 & 2 & 0.1 & & 0.2 & 0.6 & & & & 0.1 \\
\hline PET & & & & & & & & & & & & & 1.2 & 1.2 & 0.2 & & 0.4 & 1.5 & & & & 0.3 \\
\hline Other & & & & & & & & & & & & & 3.5 & 3.3 & 2.4 & & 2.7 & 2.9 & & & & 1.9 \\
\hline Other (\%w/w) & & & & & 8.2 & $13-18$ & 13.4 & 1.1 & 6.8 & 11.7 & & 10.0 & 9.3 & 9.8 & 9.7 & 31.7 & 9.3 & 9.8 & 12.9 & 11.3 & 13.2 & 14.4 \\
\hline $\begin{array}{l}\text { Incombustible } \\
\text { material }\end{array}$ & & & & & 4.7 & & 4 & & & 11.7 & & 5.8 & 4.7 & 4.9 & 5.9 & 29.5 & 5.2 & 7.0 & & & 8.2 & 8 \\
\hline Inert material & & & & & 0.7 & & 4 & 4 & 1.5 & & & 2.6 & 3.2 & 2.6 & 1.9 & & 2.1 & 3.2 & & & 0.5 & 5 \\
\hline Other & & & & & 4 & & & 5.1 & & & & 3.2 & 1.5 & 2.3 & 4 & & 3.1 & 3.8 & & & 7.7 & 3 \\
\hline $\begin{array}{l}\text { Other combustible } \\
\text { material }\end{array}$ & 4.5 & 3.4 & 2.4 & 1.7 & 3.5 & $13-18$ & 9.4 & 9.1 & 3.7 & & & 4.2 & 4.6 & 4.9 & 3.8 & 2.2 & 4.1 & 2.8 & & & 5.0 & 6.4 \\
\hline Textile & & & & & & & & & & & & & 1.9 & 2.1 & 1.7 & 1.5 & 1.6 & 1.8 & & & & 2.1 \\
\hline Leather, rubber & & & & & & & & & & & & & 0.7 & 0.8 & 0.4 & & 0.6 & 0.8 & & & & 0.6 \\
\hline Wood & & & & & & & & & & & & & 2 & 2 & 1.7 & 0.7 & 1.9 & 2 & & & & 3.7 \\
\hline Density $\left(\mathrm{kg} / \mathrm{m}^{3}\right)$ & & & & & 167.2 & & & & & & & 119.8 & 113 & 113.1 & 137.9 & & 108.7 & 121.9 & & & & 80.7 \\
\hline$\Delta \mathrm{H}_{\mathrm{in}}(\mathrm{kJJ} / \mathrm{kg})$ & 6,884 & 6,132 & 6,324 & 6,675 & 7,315 & & 4,381 & & & & & 4,844 & 7,289 & 7,089 & 7,071 & & & 7,678 & & & & 7,327 \\
\hline Combustible (\% w/w) & & & & & 28.7 & & & & & & & 34.5 & 45.3 & & 45.9 & & & & & & & 48.1 \\
\hline Wet $(\%$ w/w) & & & & & 37.5 & & & & & & & 30.2 & 31.4 & & 40.8 & & & & & & & 37.5 \\
\hline Ash $(\% \mathrm{w} / \mathrm{w})$ & & & & & 33.8 & & & & & & & 35.3 & 23.3 & & 13.3 & & & & & & & 14.4 \\
\hline$>120 \mathrm{~mm}(\% \mathrm{w} / \mathrm{w})$ & & & & & 31.2 & & & & & & & 38.3 & & & & & & & & & & \\
\hline $40-120 \mathrm{~mm}(\% \mathrm{w} / \mathrm{w})$ & & & & & 34.1 & & & & & & & 45.7 & & & & & & & & & & \\
\hline$\angle 40 \mathrm{~mm}(\% \mathrm{w} / \mathrm{w})$ & & & & & 34.7 & & & & & & & 16.0 & & & & & & & & & & \\
\hline C:N Ratio (-) & & & & & & & 22.5 & & & & & 18.5 & & & & & & & & & & \\
\hline
\end{tabular}


Table 2. MSW generation rates in Greece

\begin{tabular}{lll}
\hline & Urban Prefectures & Semi-rural Prefectures \\
\hline Waste generation rate & $1.25 \mathrm{~kg} \mathrm{person}^{-1}$ day $^{-1}$ & $1 \mathrm{~kg} \mathrm{person}^{-1}$ day $^{-1}$ \\
\hline
\end{tabular}

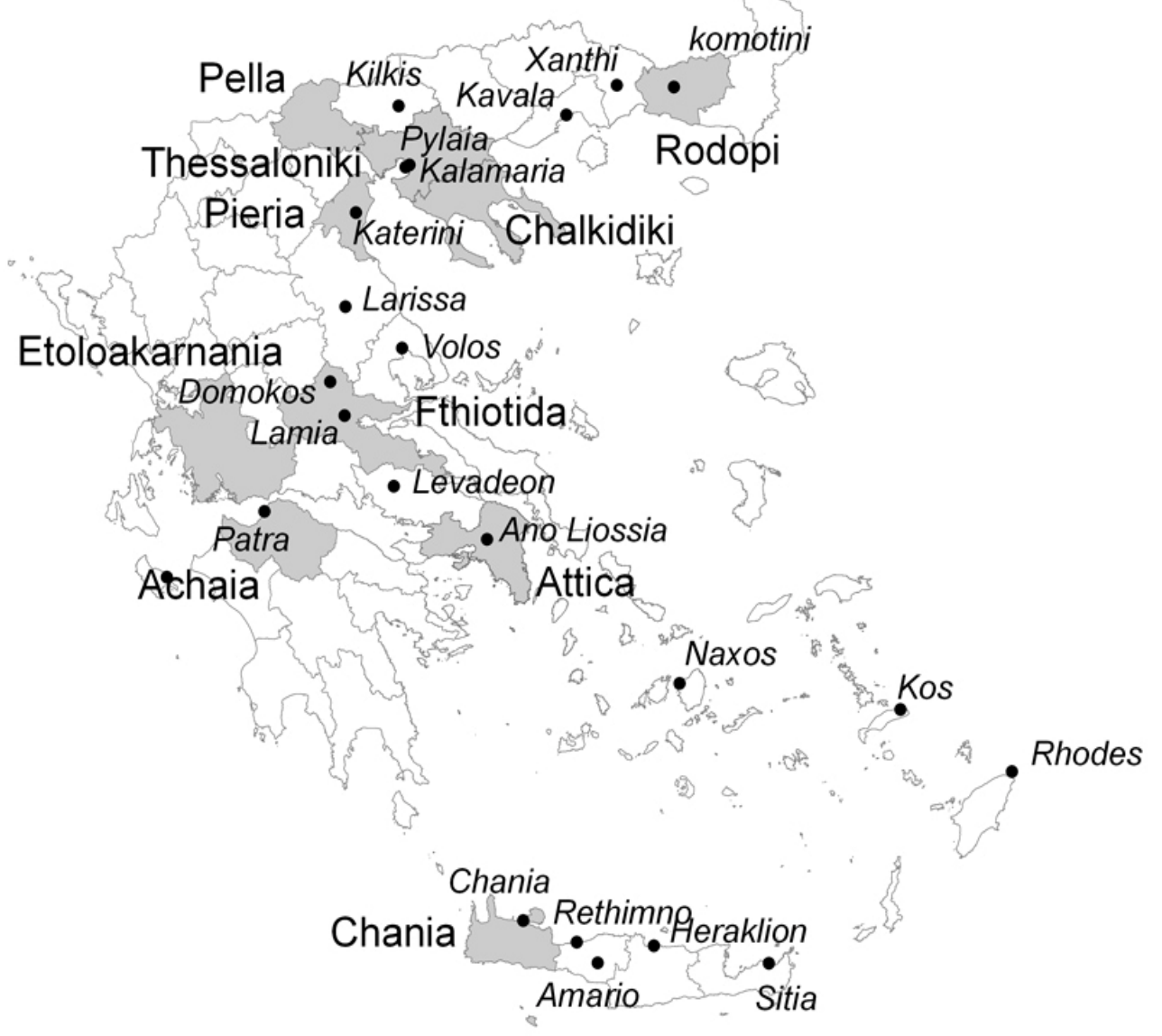

Figure 1. Locations in Greece of cities and prefectures cited in table 3. Cities are written in italics; prefectures are written in larger-size writing

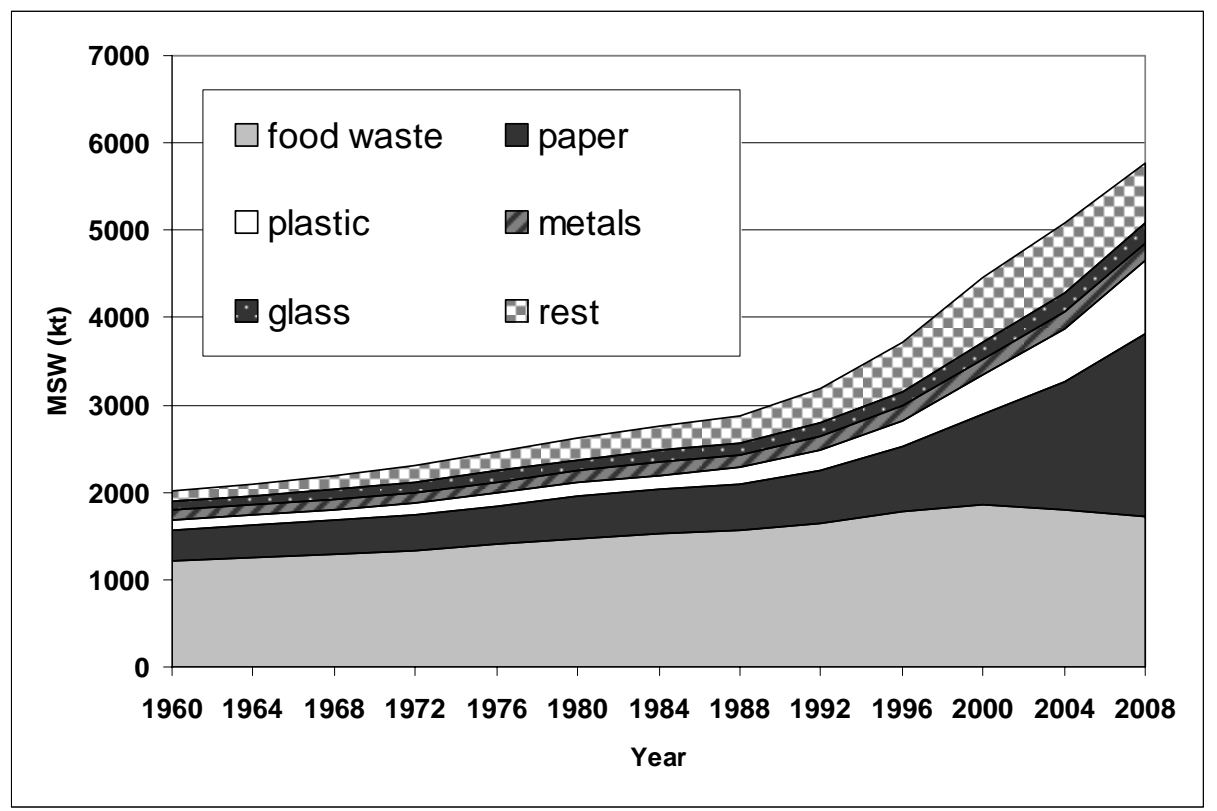

Figure 2. History of municipal solid waste generation in Greece and its composition (time series compiled by authors) 


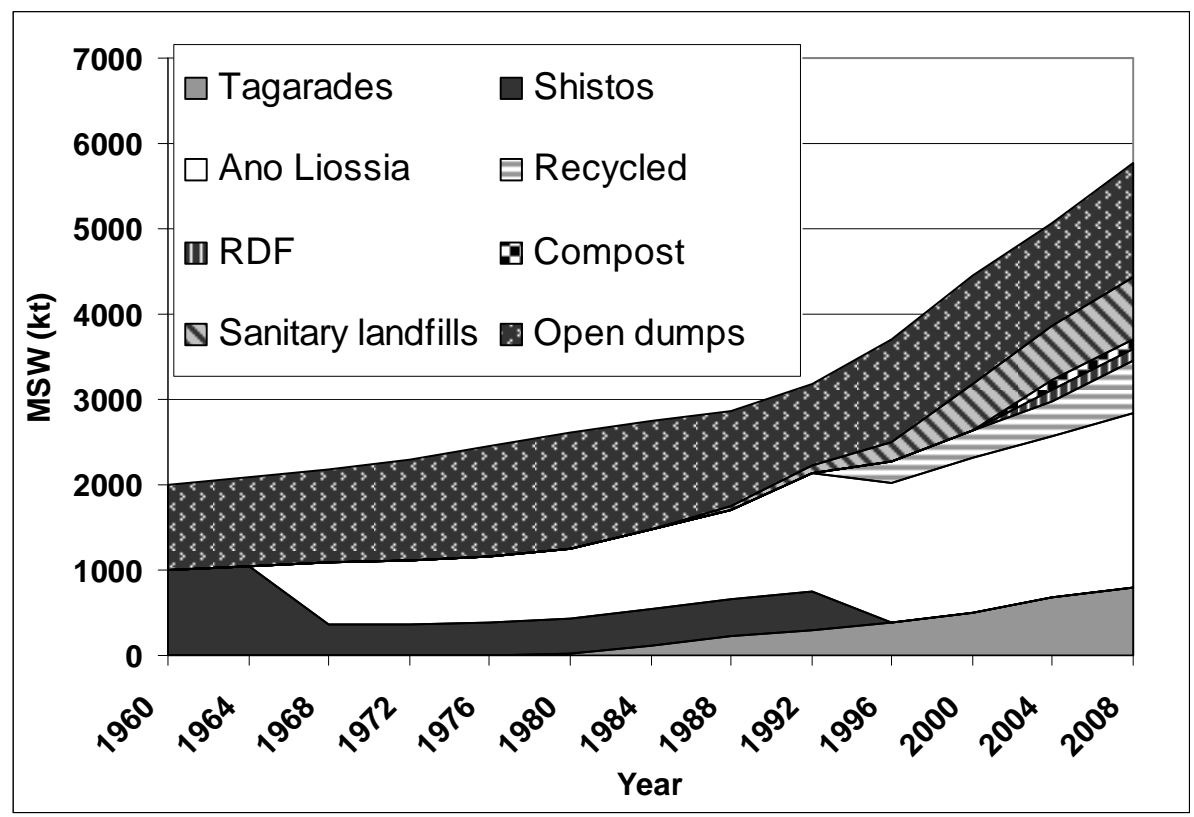

Figure 3. History of solid waste management in Greece (time series compiled by authors)

\section{RESULTS}

\subsection{Overall methane production}

Assumed recycling of landfilled paper and composting of food waste in the landfill directive scenario, led to a foreseen reduction of degradable deposited waste and, therefore, maximum methane production was nearly $60 \%$ lower than that in the do-nothing scenario. Figure 4 illustrates the calculated overall production of methane for the period 1960-2028 from Hellenic landfills. Official national estimations for the period 1990-2005 are also included (Ministry for the Environment, Physical Planning and Public Works, 2007).

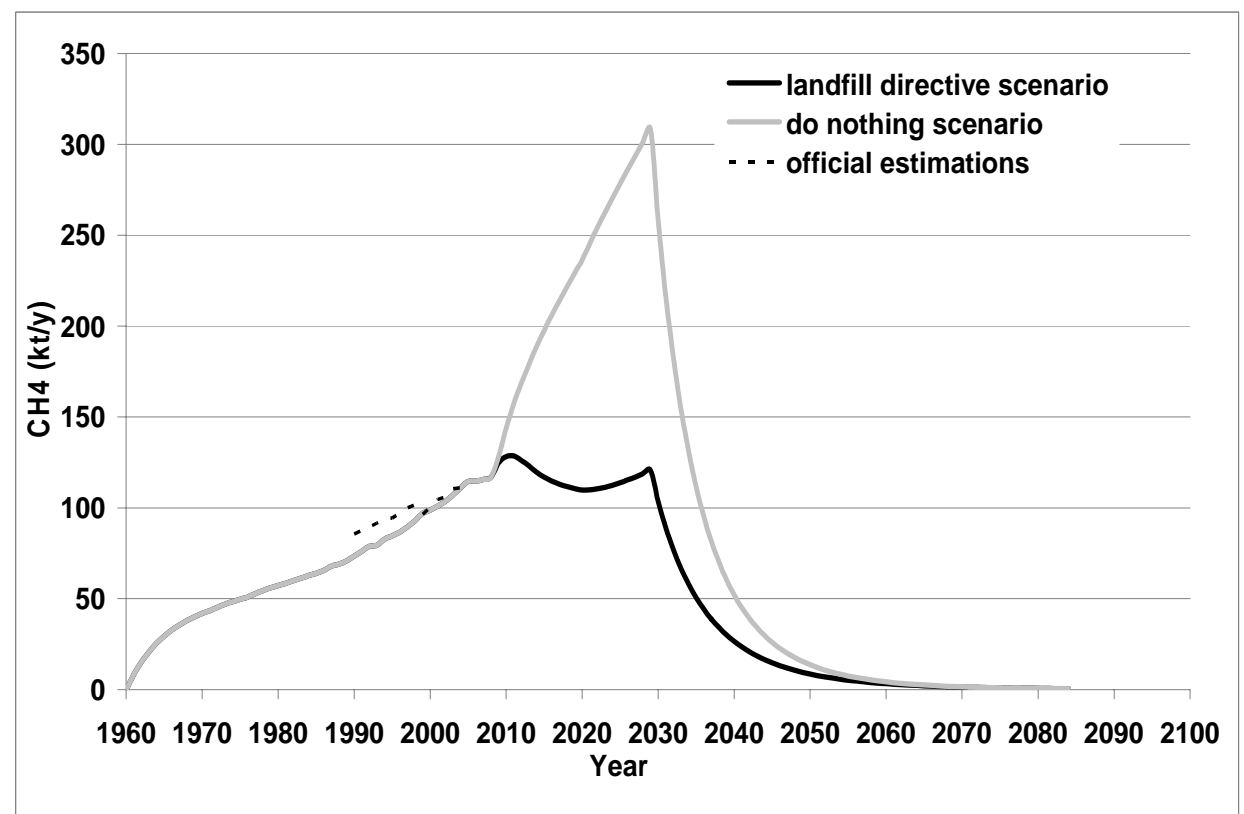

Figure 4. Calculated annual methane generation from Hellenic sanitary landfills and the semi-controlled landfills of Shisto, Ano Liossia and Tagarades

It can be observed that current calculations and official estimations are similar for the period 2000-2005, but there is a difference of $12-16 \%$ for the years 1990-1999. This difference may be justified by the fact that the older official calculations were made using a zero-order model, 
which is considered to produce less reliable results. Although the landfill directive scenario is considered as the closest one to the foreseen future reality, deviations may occur from the prescribed goals.

\subsection{Sensitivity analysis}

In order to examine and specify the effect of the selected coefficients to the overall LFG production, a sensitivity analysis was conducted by means of certain variations of waste production rates and reaction rate constants. Calculations presented next were conducted for the Etoloakarnania Prefecture. Etoloakarnania was chosen due to its population which is average in comparison to all the Hellenic Prefectures and its climate, which presents variations on temperature and humidity from low lying to mountain areas that would affect half life of deposited materials.

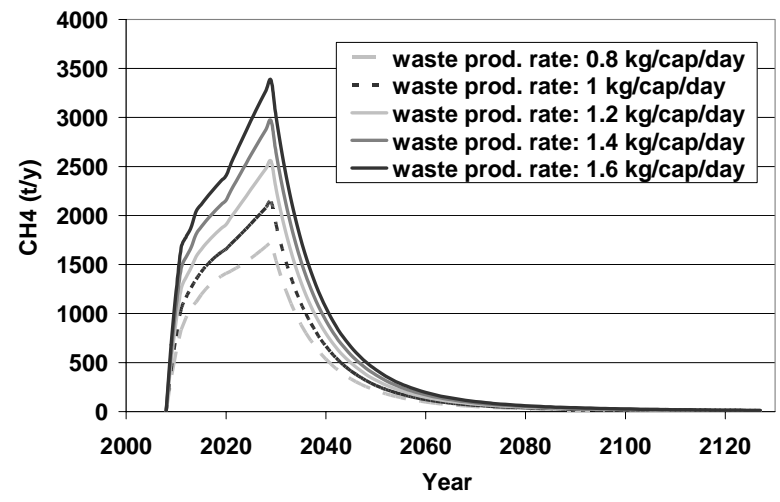

Figure 5. $\mathrm{CH}_{4}$ production in Etoloakarnania landfill for 4 different waste production rates.

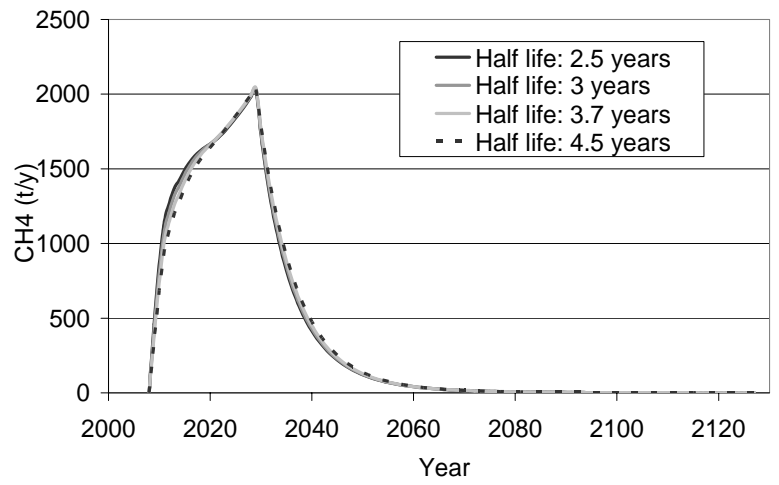

Figure 6. $\mathrm{CH}_{4}$ production in Etoloakarnania landfill for 4 half lifes of food waste.

Figure 5 validates the expected direct correlation between waste production rates and estimated LFG production. Peak values of methane generation are $20 \%$ higher between 0.8 and $1 \mathrm{~kg}$ person ${ }^{-1}$ day $^{-1}, 16 \%$ between 1 and $1.2 \mathrm{~kg} \mathrm{person}^{-1}$ day $^{-1}$ and $14 \%$ higher between 1.2 and $1.4 \mathrm{~kg}$ person ${ }^{-1} \mathrm{day}^{-1}$, which correspond to the increase (in percentage) of waste production rates.

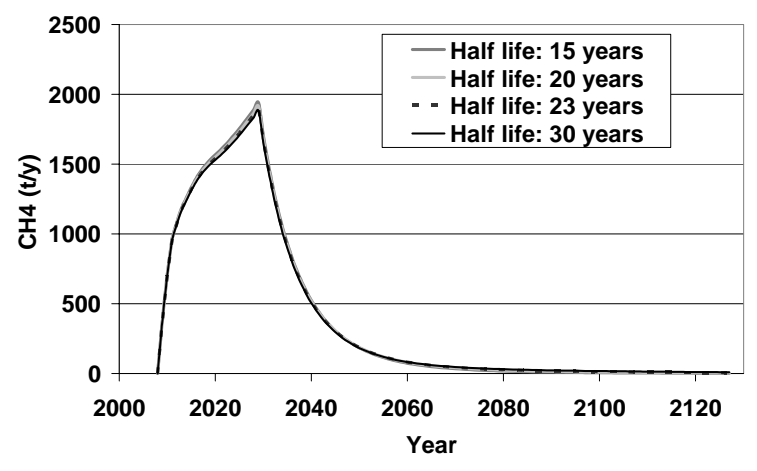

Figure 7. $\mathrm{CH}_{4}$ production in Etoloakarnania landfill for 4 half lifes of wood \& leather.

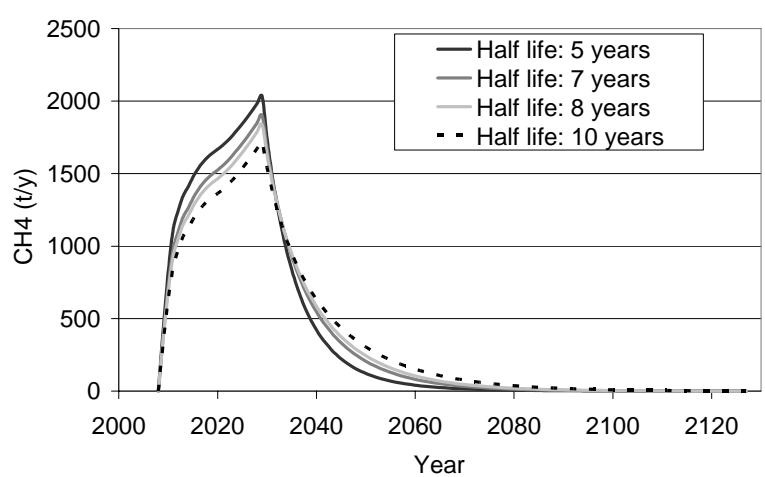

Figure 8. $\mathrm{CH}_{4}$ production in Etoloakarnania landfill for 4 different half lifes of waste paper.

The effect of the selected half-life duration of food waste, paper, wood and textiles to the overall methane production was also calculated. Half life of the materials is related to the reaction rate $(k)$ of the model through the equation $k=t_{1 / 2}{ }^{-1} \ln 2$. According to the results, halflife variations of food waste, wood and textiles (Figures 6,7 ) do not alter methane estimations significantly. Regarding food waste, peak values of methane production are almost the same in each case, with less than $1 \%$ difference to each other. This may be justified by the fact that half lives of food waste are too short anyway for their further partial differentiation to affect the 
results significantly. Methane production for a half life of wood and textiles between 15 and 30 years appears almost identical, indicating that their variation does not affect it significantly as well (Figure 7). This may be caused by the fact that the amounts of wood and textiles are small in comparison to the other materials that are deposited in landfills, leading to proportionally small contribution to methane production. On the contrary, variation of the half time of paper seems to affect the methane production curve (Figure 8). Between half lives of 6,7 and 8 years, differences are less than 1\%, but if the half life of paper is doubled from 5 to 10 years, (in more arid areas for example), then the maximum methane generation drops more than $20 \%$, leading to a smoother curve.

\subsection{Practical guidelines for landfill gas utilization}

From a technical point of view, the utilization of landfill gas can be achieved for even small landfills, for example for a Hellenic city of $30,000-40,000$ people, which produces around $10,000 \mathrm{t}$ of MSW year ${ }^{-1}$. If this amount of waste is landfilled for more than 8 years, it will eventually produce $140 \mathrm{~m}^{3}$ LFG $\mathrm{h}^{-1}$, which consists the lower limit to feed an internal combustion engine of $250 \mathrm{~kW}$. However, it was calculated that such an investment would not result to profit, as the equivalent cost for construction and operation of this facility is marginally lower than the profit from selling the produced electricity. On the other hand, for a larger sanitary landfill which receives e.g. more than 100,000 t MSW year ${ }^{-1}$, a LFG-to-energy facility of $1 \mathrm{MW}$ could be sustained. Such a facility was estimated to be profitable after about 10 years of operation and is obviously among the main reasons and drivers for the existing facilities at Ano Liossia (13.9 MWe $)$ and Tagarades (5 MWe).

Except from internal combustion engines, all other major technologies for LFG management and utilization and their $\mathrm{CH}_{4}$ working limits are depicted in figure 9. In case of old waste disposal sites where $\mathrm{CH}_{4}$ concentration is low, landfill gas management can be achieved by flaring, biofilters, aeration and even fluidized bed combustion (Steinbrecht and Spiegelberg, 2007, Stachowitz, 2003).

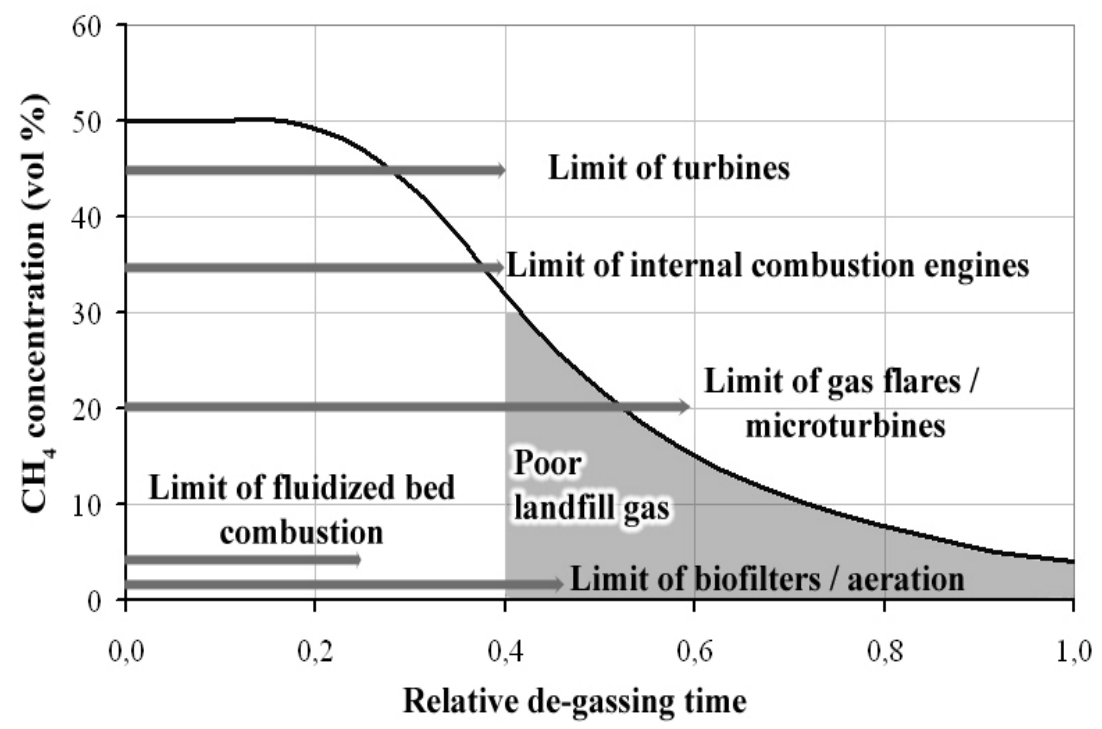

Figure 9. Lower $\mathrm{CH}_{4}$ working limits for LFG utilization - management facilities.

The value ' 1,0 ' of relative de-gassing time is e.g. 50 years

\section{Conclusions}

(Steinbrecht and Spiegelberg, 2007; Stachowitz, 2003).

Methane contained in LFG to be generated from new Hellenic landfills is generally able to sustain LFG-to-energy systems, even if the objectives of the landfill directive (setting limits to the amount of biodegradable and packaging materials to be deposited in landfills) are strictly and timely achieved. This result is mainly justified by the fact that landfills are still the prevailing option in Hellenic solid waste management in the majority of its Prefectures and this status seems that will not radically change in the following years. Currently in Greece,18.9 $\mathrm{MW}_{\mathrm{e}}$ are generated from LFG-to-energy systems. Landfill operators in Greece lately seem to be generally in favour of LFG-to-energy projects, as currently (2008), the price 
of electricity produced by LFG is set at $75,82 € \mathrm{MWh}_{\mathrm{e}}^{-1}$ and regulated as an alternative energy source. Many sanitary landfill operators in Greece that were interviewed concerning the options of biogas recovery showed unwillingness to go into early gas collection and treatment from the first months of landfill operation, which although partly understandable from a financial standpoint is surely not acceptable environmentally or even under certain health and safety considerations. The early installation of the growing ICE-electricity pair is not necessary (especially since it is coupled with high investment costs, in the range of 3-4 M€ $\mathrm{MW}_{\mathrm{e}}^{-1}$ ) but the early installation and operation of the capture network may be combined with other aforementioned techniques for poor LFG-treatment at the early landfill stages; in this context, horizontal collection pipelines, which are already been installed in various new Hellenic sanitary landfills, show some advantages over the traditional vertical wells in terms of early installation potential, since vertical wells can only be operated after the final landfill height has been reached.

The success of a LFG-to-energy project is thus highly dependant to an accurate and timely estimation of the produced LFG, as an overestimation could lead to its failure. This estimation depends on the accuracy of the selected model, the quality of available data and the selection of the correct coefficients. Sensitivity analysis in the present study has shown that methane production as estimated by this model is strongly influenced by the estimated waste production rate; therefore, in the case that future waste production rates are increased, methane production will rise as well by at least $15 \%$. On the other hand, the half-life periods of food waste, wood and textiles do not influence methane production as estimated by this specific model, with only the half life of paper seeming to notifiable change the methane production curve. Beside direct combustion for energy recovery, other issues related to LFG management at Hellenic landfills that will have a key role in the future will include LFG upgrading for injection in the natural gas network, as well as 'weak' gas management by a variety of techniques including aeration, biofiltering, flaring and fluidised bed combustion.

Finally it should be noted that there is a clear need to increase the capture rate of the produced biogas from the early landfill stages. The currently very useful Hellenic practical guidelines on landfill management, which are also available in the form of a practical manual to the landfill operators, need therefore to be enriched with further ways to go about daily landfill operations in order to support and facilitate this goal as well.

\author{
Acronyms \\ DOC Degradable Organic Carbon \\ IPCC Intergovernmental Panel on Climate Change \\ LFG Landfill Gas \\ MCF Methane Correction Factor \\ MSW Municipal Solid Waste \\ UNFCCC United Nations Framework Convention on Climate Change
}

\title{
REFERENCES
}

Coops O., Luning L., Oonk H. and Weenk A., (1995), Validation of landfill gas formation models, Fifth international landfill symposium, Sardinia, Italy, pp. $635-746$.

Cossu R., Andreottola G. and Muntoni A., (1996), Modelling landfill gas production, In: Landfilling of waste: biogas, Christensen TH, Cossu R, Stegmann R (eds), Spon, London, pp. 237-268.

Deed C., Cronow J., Rosevear A., Braithwaite P., Smith R. and Stanley P., (2004), Guidance on gas treatment technologies for landfill gas engines, R\&D Technical Report P1-330, Environment Agency, Bristol, UK.

European Commision (1991) Council Directive 199/31/EC of 26 April 1999 on the landfill of waste, Official Journal, L182, 1-19.

Falzon J., (1997), Landfill Gas: An Australian Perspective, Sixth International Landfill Symposium, Sardinia, Italy, 2, 487-496.

Farquhar G.J. and Rovers S.A., (1973), Gas production from landfill decomposition, Water, Soil and Air Pollution, 2, 493.

Ham R.K., (1979), Predicting gas generation from landfills, Waste Age. 
Hellenic Official Gazette, (2003), Common Ministerial Decision 50910/2727/22-12-2003, Measurements and terms for solid waste management. National planning for solid waste management. B' 1909 (in Hellenic).

Lamborn J., (1999), Modelling landfill gas generation, 2nd UNEP Asia-Pacific Cleaner Production roundtable, April, Brisbane Australia.

Meraz R-L., Vidales A-M., and Dominguez A., (2004), A fractal-like kinetics equation to calculate landfill methane production, Fuel, 83, 73-80.

Ministry for the Environment, Physical Planning and Public Works. (2007), National inventory for greenhouse and other gases for the years 1990-2005. September.

Munoz J.J, Lobo A.G., Szanto M.N. and Tejero I.M., (2003), Daily evolution of the biogas emissions in the meruelo landfill (Spain), Ninth International Waste Management and Landfill Symposium, Sardinia, Italy.

Nikiema J., Bibeau L., Lavoie J., Brzezinski R., Vigneux, J. and Heitz M., (2005), Biofiltration of methane: An experimental study, Chemical Engineering Journal, 113, 111-117.

Pacey J. and Augenstein D., (1990), Modelling landfill methane generation. Conference Proceedings, Landfill Gas: Energy and Environment '90, Bournemouth, England, pp. 223 263.

Parker T., Dottridge J. and Kelly S., (2002), Investigation of the Composition and Emissions of Trace Components in Landfill Gas, R\&D Technical Report P1-438/TR, Environment Agency, Bristol, UK.

Qin W., Egolfopoulos F.N. and Tsotsis T.T., (2001), Fundamental and environmental aspects of landfill gas utilization for power generation, Chemical Engineering Journal, 82, 157-172.

Rees J.F., (1980), The fate of organic carbon compounds in the landfill disposal of organic matter, Journal of Technology and Biotechnology, 30, 361.

Richards K.M., Maulder D.H. and Gorman J.F., (1992), Landfill gas: the energy - environment paradox, Workshop, Landfill gas applications and opportunities, University of Melbourne.

Scharff $\mathrm{H}$. and Jacobs J., (2006), Applying guidance for methane emission estimation for landfills, Waste Management, 26, 417-429.

Stachowitz W.H., (2003), Overview of methane oxidization at (old) landfills - global CO2 consideration, Trade with $\mathrm{CO} 2$ - certificates, Proceedings 9th International Waste Management and Landfill Symposium, Sardinia.

Steinbrecht D. and Spiegelberg V., (2007), New DN-ES+S landfill aftercare conception based on a fluidized bubling bed combustion plant burning very poor landfill gas, 2nd BOKU waste conference, pp. 175-184.

Tchobanoglous G., Theisen H. and Eliassen R., (1993), Integrated SWM, McGraw-Hill.

Themelis N. and Karagiannidis A., (2008), Expanding the Waste Management Hierarchy for Reducing Methane Emissions from Landfills, Venice 2008 Symposium, (in press).

Tsatsarelis T., Karagiannidis A. and Perkoulidis G., (2006a), Technologies of landfill gas management and utilization, Protection and Restoration of the Environment VIII, Chania, 3-7 July, CD ROM version.

Tsatsarelis T., Karagiannidis A. and Perkoulidis G., (2006b), Estimation of methane potential from the biogas of the new Hellenic sanitary landfills, Anaerobe biologische Abfallbehandlung, Dresden Germany, 27 - 28 September, pp. 232-245. 